\title{
GABA Is Excitatory in Adult Vasopressinergic Neuroendocrine Cells
}

\author{
Juhee Haam, ${ }^{1}$ Ion R. Popescu, ${ }^{1}$ Linda A. Morton, ${ }^{1}$ Katalin C. Halmos, ${ }^{1}$ Ryoichi Teruyama, ${ }^{3}$ Yoichi Ueta, ${ }^{4}$ \\ and Jeffrey G. Tasker ${ }^{1,2}$ \\ ${ }^{1}$ Department of Cell and Molecular Biology and ${ }^{2}$ Neuroscience Program, Tulane University, New Orleans, Louisiana 70118, ${ }^{3}$ Department of Biological \\ Sciences, Louisiana State University, Baton Rouge, Louisiana 70803, and ${ }^{4}$ Department of Physiology, University of Occupational and Environmental Health, \\ Kitakyushu 807-8555, Japan
}

Neuronal excitability in the adult brain is controlled by a balance between synaptic excitation and inhibition mediated by glutamate and $\mathrm{GABA}$, respectively. While generally inhibitory in the adult brain, $\mathrm{GABA}_{\mathrm{A}}$ receptor activation is excitatory under certain conditions in which the GABA reversal potential is shifted positive due to intracellular $\mathrm{Cl}^{-}$accumulation, such as during early postnatal development and brain injury. However, the conditions under which GABA is excitatory are generally either transitory or pathological. Here, we reveal GABAergic synaptic inputs to be uniformly excitatory in vasopressin (VP)-secreting magnocellular neurons in the adult hypothalamus under normal conditions. The GABA reversal potential $\left(E_{\mathrm{GABA}}\right)$ was positive to resting potential and spike threshold in VP neurons, but not in oxytocin (OT)-secreting neurons. The VP neurons lacked expression of the $\mathrm{K}^{+}{ }_{-} \mathrm{Cl}^{-}$cotransporter 2 (KCC2), the predominant $\mathrm{Cl}^{-}$ exporter in the adult brain. The $E_{\mathrm{GABA}}$ was unaffected by inhibition of KCC2 in VP neurons, but was shifted positive in 0T neurons, which express KCC2. Alternatively, inhibition of the $\mathrm{Na}^{+}-\mathrm{K}^{+}-\mathrm{Cl}^{-}$cotransporter 1 (NKCC1), a Cl${ }^{-}$importer expressed in most cell types mainly during postnatal development, caused a negative shift in $E_{\mathrm{GABA}}$ in VP neurons, but had no effect on GABA currents in OT neurons. GABA receptor blockade caused a decrease in the firing rate of VP neurons, but an increase in firing in OT neurons. Our findings demonstrate that GABA is excitatory in adult VP neurons, suggesting that the classical excitation/inhibition paradigm of synaptic glutamate and GABA control of neuronal excitability does not apply to VP neurons.

\section{Introduction}

Magnocellular neuroendocrine cells in the paraventricular nucleus (PVN) and supraoptic nucleus (SON) of the hypothalamus play an important role in regulating fluid balance, reproductive functions, and energy homeostasis. Magnocellular neurons secrete either oxytocin (OT) or vasopressin (VP) (Mohr et al., 1988; Kiyama and Emson, 1990), and neuropeptide secretion from these neurons is closely related to their firing frequency and pattern (Dreifuss et al., 1971; Dutton and Dyball, 1979). Synaptic activity is a key regulator of the firing activity in magnocellular neurons (MacVicar et al., 1982). Approximately $60 \%$ of the total number of synapses in the SON and PVN are GABAergic, indicating a significant role for GABA in the synaptic regulation of the magnocellular neurons (Decavel and Van den Pol, 1990; El Majdoubi et al., 1997). GABA is generally inhibitory in the adult

\footnotetext{
Received July 26, 2011; revised 0ct. 18, 2011; accepted Nov. 9, 2011

Author contributions: J.H., I.R.P., and J.G.T. designed research; J.H., I.R.P., L.A.M., K.C.H., and R.T. performed research; Y.U. contributed unpublished reagents/analytic tools; J.H. and I.R.P. analyzed data; J.H., I.R.P., and J.G.T. wrote the paper.

This work was supported by NIH Grant NS042081, the Tulane Research Enhancement Fund, and the Catherine and Hunter Pierson Chair in Neuroscience. We thank Drs. Harold Gainer and Alan Robinson for generously providing antibodies.

The authors declare no competing financial interests.

Correspondence should be addressed to Jeffrey Tasker, Department of Cell and Molecular Biology, 2000 Percival Stern Hall, Tulane University, New Orleans, LA 70118. E-mail: tasker@tulane.edu.

DOI:10.1523/JNEUROSCI.3826-11.2012

Copyright $\odot 2012$ the authors $\quad 0270-6474 / 12 / 320572-11 \$ 15.00 / 0$
}

brain, but it also can mediate excitatory synaptic responses under conditions of high intracellular $\mathrm{Cl}^{-}$concentration. A low intracellular $\mathrm{Cl}^{-}$concentration, as it is in most neurons of the adult brain, causes $E_{\mathrm{GABA}}$ to be negative to resting membrane potential, which leads to outward membrane currents and inhibitory synaptic signals upon opening of $\mathrm{GABA}_{\mathrm{A}}$ receptor channels. A high intracellular $\mathrm{Cl}^{-}$concentration, however, can cause $E_{\mathrm{GABA}}$ to be positive to resting potential and $\mathrm{GABA}_{\mathrm{A}}$ receptor activation to generate inward membrane currents and depolarizing synaptic signals (Misgeld et al., 1986; Prescott et al., 2006; Choi et al., 2008).

The concentration of intracellular $\mathrm{Cl}^{-}$ions in neurons is mainly controlled by two $\mathrm{Cl}^{-}$transporters, NKCC1 and KCC2. NKCC1 accumulates $\mathrm{Cl}^{-}$ions inside cells by the cotransport of $\mathrm{Cl}^{-}$into cells using the $\mathrm{Na}^{+}$concentration gradient; KCC2, on the other hand, exports $\mathrm{Cl}^{-}$from cells by the cotransport of $\mathrm{Cl}^{-}$ out of cells using the $\mathrm{K}^{+}$concentration gradient (Payne et al., 1996; Plotkin et al., 1997). The expression and activity of the $\mathrm{Cl}^{-}$ transporters are regulated by various factors, including development, activity, and stress (Rivera et al., 1999; Wardle and Poo, 2003; Woodin et al., 2003; Cordero-Erausquin et al., 2005; Fiumelli et al., 2005; Hewitt et al., 2009). Recent studies have shown that the $\mathrm{Cl}^{-}$transporters are expressed in a cell typespecific manner. For example, VP neurons in the hypothalamus have been shown not to express detectable levels of KCC2 in immunohistochemical studies (Kanaka et al., 2001; Belenky et al., 2008). Interestingly, GABA was shown to reduce the 
firing activity of OT neurons but not VP neurons in vivo, suggesting a lack of inhibitory action of GABA in VP neurons (Engelmann et al., 2004).

Previous in vitro studies showing GABA as an inhibitory neurotransmitter in the PVN and SON were conducted using intracellular or patch-clamp recordings (Wuarin and Dudek, 1993; Boudaba et al., 1996), which disrupt the normal $\mathrm{Cl}^{-}$ concentration gradient. In the present study, we used gramicidin-perforated patch-clamp recordings and loose-seal patch extracellular recordings, both of which do not disturb the $\mathrm{Cl}^{-}$ concentration gradient, as well as immunohistochemical analyses, to study GABA-mediated synaptic currents and action potential generation in OT and VP magnocellular neurons of the SON and PVN.

\section{Materials and Methods}

Animals. We used 5-12 week old male wild-type and transgenic Wistar rats that express VP-eGFP fusion protein in VP neurons according to a protocol approved by the Tulane University Institutional Animal Care and Use Committee and in accordance with US Public Health Service guidelines. The VP-eGFP transgenic rat colony was established from founders provided by Dr. Yoichi Ueta of the University of Occupational and Environmental Health in Japan (Ueta et al., 2005). Wild-type rats were purchased from Harlan and were allowed to acclimate to their living quarters for at least a week before being used for experiments. All rats had ad libitum access to water and food.

Slice preparation. Rats were deeply anesthetized with isoflurane inhalation (VetOne, Meridian, ID) and decapitated using a rodent guillotine. The brain was quickly removed from the cranial cavity after cutting the optic nerves and immersed in a cooled $\left(1-2^{\circ} \mathrm{C}\right)$ artificial CSF (aCSF) bubbled with $100 \% \mathrm{O}_{2}$. The composition of the aCSF for dissection and electrophysiological recordings was (in $\mathrm{mm}$ ): $140 \mathrm{NaCl}, 3 \mathrm{KCl}, 1.3$ $\mathrm{MgSO}_{4}, 1.4 \mathrm{NaH}_{2} \mathrm{PO}_{4}, 2.4 \mathrm{CaCl}_{2}, 11$ glucose, and 5 HEPES; pH was adjusted to 7.2-7.4 with $\mathrm{NaOH}$. The hypothalamus was blocked and glued to the chuck of a vibrating microtome with the rostral side up. Two or three 300- $\mu \mathrm{m}$-thick coronal hypothalamic slices containing the PVN and/or SON were sectioned and bisected along the midline, and the hemi-slices were maintained submerged in a holding chamber in oxygenated aCSF at room temperature, where they were allowed to equilibrate for at least $1 \mathrm{~h}$ before being transferred to the recording chamber.

Electrophysiological recording materials and methods. All electrophysiological recordings were performed in visualized individual PVN and SON magnocellular neurons in acute hypothalamic slices maintained at a temperature of $30^{\circ} \mathrm{C}$. Patch-clamp electrodes were pulled from borosilicate glass capillary tubes $(1.65 \mathrm{~mm}$ outer diameter, $1.2 \mathrm{~mm}$ inner diameter; KG33; King Precision Glass) with a Flaming/Brown P-97 micropipette puller (Sutter Instruments) to a resistance of 3-6 $\mathrm{M} \Omega$. Pipette solutions contained (in mM) $120 \mathrm{~K}$-gluconate, $10 \mathrm{KCl}, 1 \mathrm{NaCl}, 1 \mathrm{MgCl}_{2}$, $1 \mathrm{CaCl}_{2}, 10$ EGTA, $2 \mathrm{Mg}$-ATP, $0.3 \mathrm{Na}$-GTP, and $10 \mathrm{HEPES}$; the $\mathrm{pH}$ of the pipette solution was adjusted to 7.3 with $\mathrm{KOH}$ and the osmolarity was adjusted to $300 \mathrm{mOsmol}$ with $20 \mathrm{~mm}$ D-sorbitol. Magnocellular neuroendocrine cells were identified in the PVN based on their large soma size, their location within the lateral magnocellular division of the nucleus, and the presence of a distinct transient outward rectification during recordings (Tasker and Dudek, 1991; Luther et al., 2000). Vasopressin neurons were distinguished by the presence of eGFP expression (Ueta et al., 2005); eGFP-negative neurons were considered to be putative OT neurons (Fig. 1A). We used $488 \mathrm{~nm}$ for excitation of GFP fluorescence. Glutamate receptor antagonists 6,7-dinitroquinoxaline-2,3-dione (DNQX, $15 \mu \mathrm{M}$ ) and DL-2-amino-5-phosphonopentanoic acid (DL-AP5, $50 \mu \mathrm{M}$ ) were bath-applied to block glutamatergic synaptic inputs and isolate GABA synaptic currents. For some experiments, the $\mathrm{GABA}_{\mathrm{A}}$ receptor antagonist bicuculline methiodide $(10-60 \mu \mathrm{M})$ was bath-applied to block synaptic GABA currents. For perforated patch-clamp recordings, gramicidin was added to the intracellular solution. Gramicidin was first dissolved in DMSO $(0.05 \mathrm{mg} / \mu \mathrm{l})$ and then diluted in the patch pipette solution to a final concentration of $100 \mu \mathrm{g} / \mathrm{ml}$ (Kyrozis and
Reichling, 1995). All recordings were performed using a Multiclamp 700A patch-clamp amplifier (Molecular Devices) and data were low-pass filtered at $2 \mathrm{kHz}$ and sampled at $10 \mathrm{kHz}$ with pClamp software (Molecular Devices). To determine the $E_{\mathrm{GABA}}$, synaptic currents were evoked by electrical stimuli ( $30-50 \mathrm{~V}$ for $0.3 \mathrm{~ms})$ applied every $10 \mathrm{~s}$ with a bipolar electrode placed dorsomedial to the PVN or SON. A Grass S48 stimulator and SIU5 stimulus isolation unit (Grass Technologies) were used to deliver the extracellular stimulation. For loose-seal cell-attached patch recordings, pipettes with a larger tip diameter (pipette resistance $=1-3$ $\mathrm{M} \Omega$ ) were used to prevent the spontaneous formation of a highresistance seal. Cells were recorded at the resting potential (i.e., injection current $=0 \mathrm{pA})$, and a high $-\mathrm{K}^{+}(10 \mathrm{mM})$ extracellular solution was used to depolarize cells, consisting of (in mM) $133 \mathrm{NaCl}, 10 \mathrm{KCl}, 1.3 \mathrm{MgSO}_{4}$, $1.4 \mathrm{NaH}_{2} \mathrm{PO}_{4}, 2.4 \mathrm{CaCl}_{2}, 11$ glucose, and 5 HEPES; $\mathrm{pH}$ was adjusted to 7.2-7.4 with $\mathrm{NaOH}$. The $10 \mathrm{~mm} \mathrm{~K}^{+}$did not have a significant effect on $E_{\mathrm{GABA}}$ in VP cells $(-33.1 \pm 3.4 \mathrm{mV}$ in $3 \mathrm{~mm}$ aCSF, $n=15 \mathrm{vs}-29.8 \pm 4.1$ $\mathrm{mV}$ in $10 \mathrm{mM} \mathrm{K}^{+}$solution, $\left.n=4 ; p=0.639\right)$. Only recordings with a seal resistance of $\leq 40 \mathrm{M} \Omega$ were considered to have a stable loose-seal configuration and were used for data analysis.

Drug application. The following drugs were stored as stock solutions in frozen aliquots $\left(-20^{\circ} \mathrm{C}\right)$ and were thawed and dissolved in aCSF to their final concentrations immediately before experiments (final concentration):

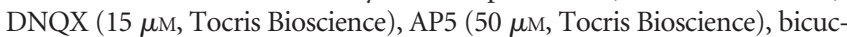
ulline methiodide (10-60 $\mu \mathrm{M}$, Ascent Scientific), bumetanide (20 or $40 \mu \mathrm{M}$, Tocris Bioscience), and VU0240551 (75 $\mu \mathrm{M}$, Tocris Bioscience). Bumetanide and VU0240551 were dissolved in DMSO or a mixture of DMSO and ethanol. All other drugs were dissolved in sterilized deionized water.

Immunohistochemical identification of recorded cells. Some SON and PVN magnocellular neurons in slices from wild-type Wistar rats were infused with biocytin (Tocris Bioscience) during recordings for subsequent immunohistochemical identification. In these recordings, $0.3 \%$ biocytin was included in the patch solution. Following perforated patch recordings and characterization of $E_{\mathrm{GABA}}$, the whole-cell configuration was achieved for 2-5 min to allow dialysis of the cell with biocytincontaining patch solution. After recording from and filling 1-2 cells in a slice with biocytin, the slices were collected and immersion fixed in $4 \%$ paraformaldehyde $/ 0.1 \%$ picric acid in $0.15 \mathrm{~m}$ sodium phosphate buffer, $\mathrm{pH} 7.2$, at $4^{\circ} \mathrm{C}$ for at least $24 \mathrm{~h}$.

Fixed slices were incubated for $24 \mathrm{~h}$ at $4^{\circ} \mathrm{C}$ in a mixture of primary antibodies that included a rabbit polyclonal antibody to VP-neurophysin (1:20,000; generously provided by Alan Robinson, UCLA, Los Angeles, CA) (Roberts et al., 1993) and a mouse monoclonal antibody to OT-neurophysin (1:500; PS38, generously provided by Harold Gainer, National Institutes of Health, Bethesda, MD) (Ben-Barak et al., 1985). Slices were then incubated overnight at $4^{\circ} \mathrm{C}$ in a mixture of secondary antibodies, including DyLight 488-conjugated goat anti-rabbit and DyLight 594-conjugated goat anti-mouse IgG (Jackson ImmunoResearch), and avidin-AMCA (7-amino-4methylcoumarin-3-acetic acid; Vector Labs) to visualize the biocytin-filled neurons. All antibodies and labeling reagents were dissolved in PBS containing $0.5 \%$ Triton X-100, and slices were washed several times in PBS/Triton X-100 between steps. Neurons were identified as either vasopressinergic or oxytocinergic only if positive staining for one of the two antibodies was complemented by a negative reaction for the other.

In vivo immunohistochemistry. Rats were deeply anesthetized with isoflurane inhalation (VetOne, Meridian, ID) and intracardially perfused with heparinized saline followed by $4 \%$ paraformaldehyde in PBS until the blood was sufficiently cleared from the circulatory system. Brains were dissected and transferred to $30 \%$ sucrose in PBS overnight. The hypothalamus was blocked and $30 \mu \mathrm{m}$ sections containing the SON and PVN were obtained using a cryostat (Model CM3050, Leica Microsystems). Sections were treated with 3\% normal goat serum (NGS) with $0.01 \%$ Triton-X and then incubated in a mouse monoclonal antibody to OT (PS 38, 1:500, generously provided by Dr. H. Gainer, National Institutes of Health,) and a guinea pig polyclonal antibody to VP (T-5048, 1:500, Peninsula Laboratories, LLC) or anti-KCC2 polyclonal antibody (1:500, Millipore) in $1 \%$ NGS in PBS overnight at $4^{\circ} \mathrm{C}$. After rinsing five times for 5 min with PBS, slices were treated with goat anti-mouse secondary antibody conjugated to Alexa Fluor 488 (A-11001, 1:400) at room 
A

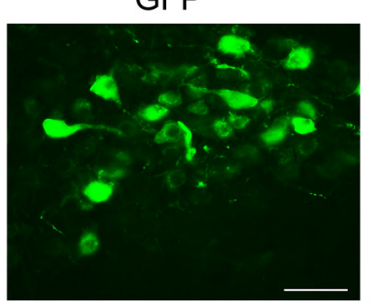

B

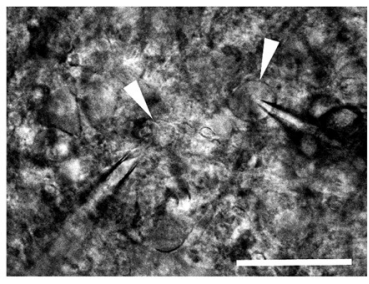

D

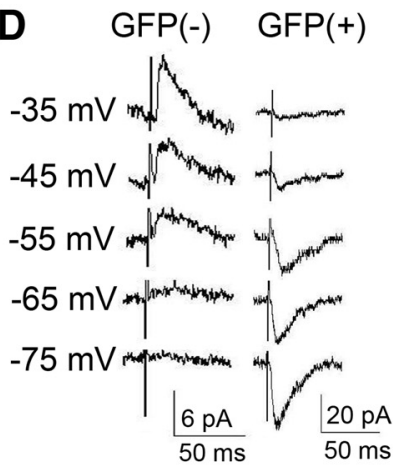

$\mathrm{VP}$
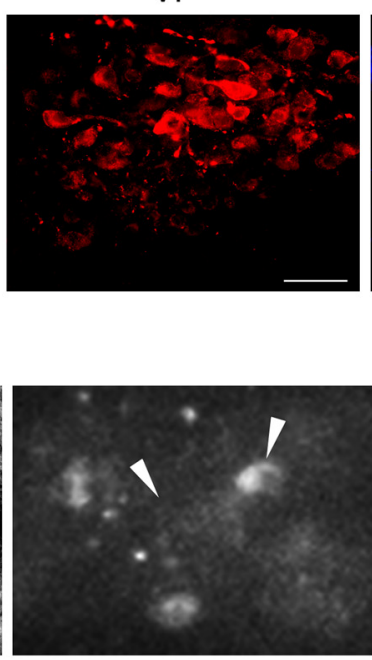

$\mathbf{E}$

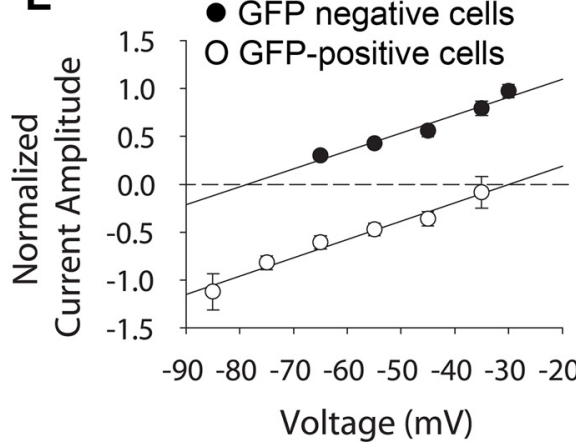

C
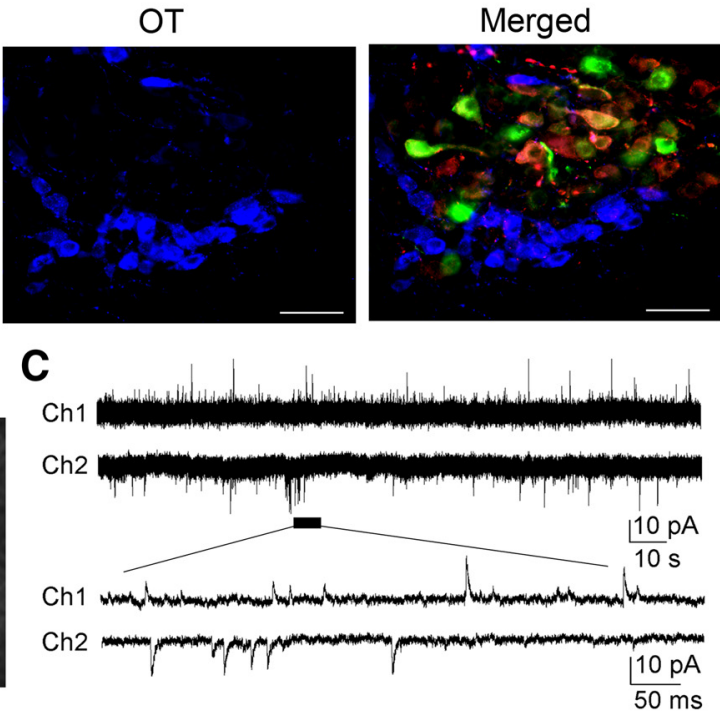

$\mathbf{F}$

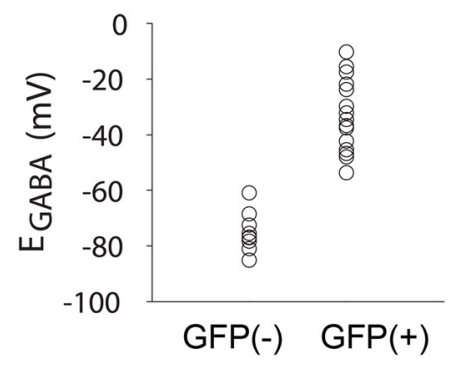

Figure 1. $E_{\mathrm{GABA}}$ is shifted positive in vasopressin neurons. $A$, Fluorescence micrographs of the same hypothalamic section showing the expression in the lateral PVN of the VP-eGFP transgene, VP immunoreactivity, OT immunoreactivity, and a merged image of the three. GFP-expressing cells were positive for VP but not for OT. $\boldsymbol{B}$, Images of the same field of the SON taken under bright field (left) and epifluorescence illumination (right), which show a GFP-negative cell (left arrowhead) and a GFP-positive cell (right arrowhead) that were pair recorded. C, Paired voltage-clamp recordings of spontaneous GABA synaptic currents in a GFP-negative cell (Ch1) and a GFP-positive cell (Ch2). At resting membrane potential (i.e., 0 pA current injection) in the presence of glutamate receptor antagonists, the polarity of the GABA currents was positive in the GFP-negative cell and was negative in the GFP-positive cell. D, Synaptic GABA currents evoked at different membrane potentials recorded in a GFP-negative (left) and a GFP-positive (right) neuron. $\boldsymbol{E}, I-V$ relationships obtained from the mean amplitudes of evoked GABA synaptic currents recorded at different holding potentials in GFP-negative cells $(n=9)$ and GFP-positive cells $(n=15)$. $\boldsymbol{F}$, Ascatter plot showing the distribution of $E_{\mathrm{GABA}}$ in GFP-negative cells $(\mathrm{GFP}(-), n=9)$ and GFP-positive cells $($ GFP $(+), n=15)$. Scale bars: $50 \mu \mathrm{m}$.

temperature for $1 \mathrm{~h}$ to stain OT neurons, with goat anti-guinea pig IgG conjugated to Alexa Fluor 546 (A-11074, 1:400) at room temperature for $1 \mathrm{~h}$ to stain VP neurons, or goat anti-rabbit IgG conjugated to Alexa Fluor 546 (A-11010, 1:400) at room temperature for $1 \mathrm{~h}$ to stain KCC2expressing neurons. All secondary antibodies were purchased from Invitrogen. After washing five times for $5 \mathrm{~min}$ with PBS, slices were mounted on coverslips with Vectashield (Vector Laboratories) and imaged on a confocal microscope (Zeiss LSM 510, Carl Zeiss AG).

Statistical analysis. Synaptic current detection analysis was performed using Mini Analysis 6.0.9 software (Synaptosoft) and pClampfit 10.2 (Molecular Devices). All data were expressed as \pm SEM. The Student's paired or unpaired $t$ test was used for within-cell comparisons and between-cell comparisons, respectively. For non-normally distributed data, determined by the Shapiro-Wilk test, the Mann-Whitney $U$ test or the Wilcoxon signed-rank test was used for within-cell and between-cell comparisons, respectively. For comparisons of more than two groups, we used the ANOVA followed by the Newman-Keuls test. Differences were considered to be statistically significant at $p<0.05$.

\section{Results}

Identification of vasopressin and oxytocin neurons

To compare GABA actions in OT and VP magnocellular neurons, we used transgenic rats that express a VP-eGFP fusion protein under the control of the VP promoter. Previous studies have shown the specific expression of eGFP in VP neurons in the SON and the PVN of these VP-eGFP transgenic rats (Ueta et al., 2005). To confirm these previous findings, we performed a qualitative immunohistochemical analysis of VP and OT labeling in SON and PVN sections from VP-eGFP rats $(n=3)$. These experiments confirmed that GFP is expressed selectively in vasopressinergic neurons and not in oxytocinergic neurons in the SON and PVN (Fig. 1A).

\section{GABA synaptic currents in GFP-positive and \\ GFP-negative neurons}

To study GABA-mediated synaptic currents without disturbing the intracellular $\mathrm{Cl}^{-}$concentration, we used the gramicidinperforated patch-clamp recording technique. After a highresistance seal was formed, cells were held in cell-attached mode at $-60 \mathrm{mV}$ and the access resistance was periodically monitored. In most of the cells, the access resistance gradually dropped to $<80 \mathrm{M} \Omega$ and the amplitude of capacitative currents reached $>200$ pA within 40 min after seal formation. Perforated-patch recordings were performed after the access resistance stabilized at 

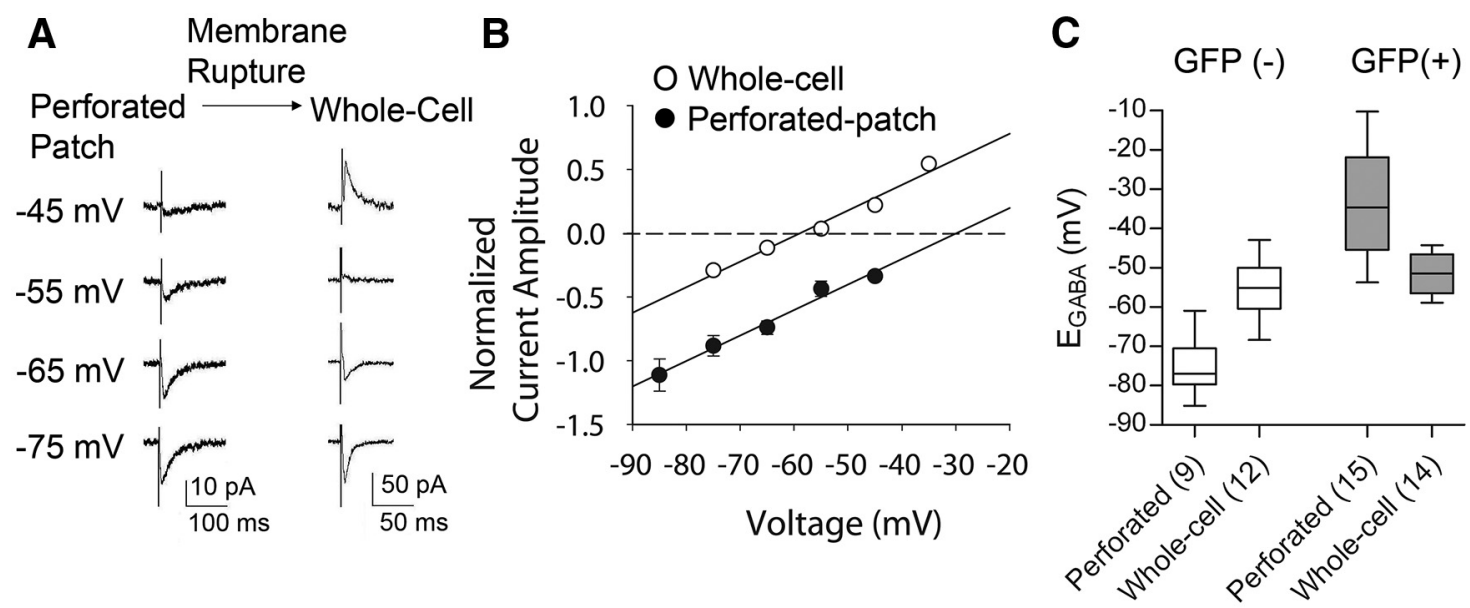

Figure 2. Perforated patch recordings maintain native intracellular $\mathrm{Cl}^{-}$concentration. $A$, Synaptic GABA currents evoked in a GFP-positive (VP) neuron at different membrane potentials and recorded in the perforated patch configuration (left) and, after rupture of the membrane, in the whole-cell configuration (right). Following membrane rupture, $E_{G A B A}$ shifted from $-29.9 \mathrm{mV}$ to $-58.9 \mathrm{mV}$ in this cell, which is close to the $E_{G A B A}$ predicted by the Nernst Equation. $B, I-V$ plot from the same GFP-positive cell showing the negative shift in the $I-V$ relationship caused by membrane rupture. This indicated that the intracellular $\mathrm{Cl}^{-}$concentration remained intact during the gramicidin perforated-patch recording. $C$, Box graph showing the mean $E_{\mathrm{GABA}}$ obtained in GFP-negative, putative 0 T neurons and GFP-positive, VP neurons during perforated-patch recordings and whole-cell recordings. The mean $E_{\text {GABA }}$ in putative $0 T$ neurons shifted from a negative potential ( $-75.1 \pm$ $2.4 \mathrm{mV})$ in perforated-patch recordings $(n=9)$ to a more positive potential $(-55.0 \pm 2.1 \mathrm{mV})$ in whole-cell recordings $(n=12)$, whereas the $E_{\mathrm{GABA}}$ in VP neurons shifted from a relatively positive potential $(-33.1 \pm 3.4 \mathrm{mV})$ in perforated-patch recordings $(n=15)$ to a more negative potential $(-51.0 \pm 1.3 \mathrm{mV})$ in whole-cell recordings $(n=14)$. The box extends from the 25 th percentile to the 75 th percentile and the line designates the median. The upward and downward bars illustrate the upper and lower limits of the range of values.

between 30 and $80 \mathrm{M} \Omega$. All perforated-patch recordings of synaptic currents were performed in the presence of the ionotropic glutamate receptor antagonists DNQX $(15 \mu \mathrm{M})$ and DL-AP5 (50 $\mu \mathrm{M}$ ) to isolate GABAergic synaptic currents (Wuarin and Dudek, 1993). In GFP-negative, putative OT neurons recorded with little or no holding current (i.e., near resting potential, $n=12$ ), spontaneous synaptic currents were outward. GFP-positive, VP neurons recorded at resting potential $(n=18)$ generated inward spontaneous synaptic currents. In simultaneous recordings of mixed pairs of GFP-positive cells and GFP-negative cells recorded at resting potential, spontaneous synaptic currents were inward in the GFP-positive cells and outward in the GFPnegative cells (Fig. 1 B,C). Both the spontaneous outward synaptic currents recorded in putative OT neurons $(n=5)$ and the spontaneous inward currents recorded in VP neurons $(n=6)$ were completely blocked with the $\mathrm{GABA}_{\mathrm{A}}$ receptor antagonist bicuculline methiodide $(60 \mu \mathrm{M})$, indicating that they were GABAergic synaptic currents and suggesting that GABA is inhibitory at resting potential in OT neurons $\left(V_{\mathrm{m}}=-53.3 \pm 2.3 \mathrm{mV}\right.$, $n=15$ ), and that, surprisingly, GABA is excitatory at resting potential in VP neurons $\left(V_{\mathrm{m}}=-53.3 \pm 1.5 \mathrm{mV}, n=22\right)$.

\section{GABA reversal potential in GFP-positive and \\ GFP-negative neurons}

The striking difference in the polarity of synaptic GABA currents at resting membrane potential between VP neurons and putative OT neurons prompted us to examine whether there is a difference in the $E_{\mathrm{GABA}}$ between the two cell groups. A current-voltage $(I-V)$ relationship of GABA currents was generated by evoking synaptic currents with extracellular electrical stimulation of afferent inputs (see Materials and Methods) at different holding potentials with ionotropic glutamate receptors blocked (in DNQX and DL-AP5) to isolate GABA currents (Fig. 1D). The $E_{\mathrm{GABA}}$ in putative OT neurons was $-75.1 \pm 2.6 \mathrm{mV}(n=9)$, whereas the $E_{\mathrm{GABA}}$ in VP neurons was significantly more positive, at $-33.1 \pm 3.4 \mathrm{mV}(n=15$, Student's $t$ test, $p<0.001)$ (Fig. $1 E, F)$. The $E_{\mathrm{GABA}}$ was negative with respect to resting potential in
OT neurons, resulting in outward GABA currents in OT neurons at rest, whereas it was positive to the resting membrane potential in VP neurons, resulting in inward GABA currents at rest.

Since male rats undergo sexual maturation at $\sim 6$ weeks of age, one possibility is that many of the magnocellular neurons that we recorded from were from rats that had not yet reached puberty and in which an excitatory-to-inhibitory developmental switch of the GABA response had not yet occurred. To control for this possibility, we divided recordings into those from young rats, aged 34-39 d, and from older rats, aged 53-80 d, and compared the $E_{\mathrm{GABA}}$ in the two groups. The $E_{\mathrm{GABA}}$ in VP neurons from the older rats $(-28.6 \pm 3.5 \mathrm{mV}, n=12)$ was not significantly different from that in neurons from the young rats $(-39.4 \pm 3.9 \mathrm{mV}$, $n=6 ; p=0.075$, Student's $t$ test) (data not shown), suggesting that the positive $E_{\mathrm{GABA}}$ is not due to immaturity of the VP neurons.

To control for the possibility that $\mathrm{Cl}^{-}$leakage from the patch pipette into the recorded cells caused experimental alteration of the intracellular $\mathrm{Cl}^{-}$concentration, after establishing the synaptic GABA current $I-V$ relationship in the cell-attached, perforated-patch recording configuration, the membrane patch was ruptured in a subset of cells by applying a slight negative pressure combined with a brief voltage pulse to obtain the wholecell configuration. The rupture of the membrane and transition to the whole-cell mode were characterized by a sudden decrease in access resistance, an increase in both membrane noise and membrane currents, and a marked increase in the amplitude of the capacitative current. After rupturing the membrane, the $E_{\mathrm{GABA}}$ in VP cells shifted negative (from $-35.7 \pm 4.5 \mathrm{mV}$ to $-51.0 \pm 2.0 \mathrm{mV} ; n=7$ ) (Fig. $2 A, B$ ), while the $E_{\mathrm{GABA}}$ in putative OT neurons shifted positive (from $-71.9 \pm 4.5 \mathrm{mV}$ to $-55.0 \pm$ $2.1, n=4)$ (data not shown). The $E_{\mathrm{GABA}}$, therefore, was more negative measured in the whole-cell configuration than in the perforated-patch configuration in VP neurons, and was more positive in the whole-cell configuration than in the perforatedpatch configuration in OT neurons, suggesting that the intracellular $\mathrm{Cl}^{-}$concentration was higher in VP neurons and lower in 
OT neurons than that in the patch solution. This suggests that the native intracellular $\mathrm{Cl}^{-}$concentration in VP neurons $(\sim 41 \mathrm{~mm})$ is higher than that in OT neurons $(\sim 8 \mathrm{mM}$, calculated according to the Nernst Equation), and that the positive $E_{\mathrm{GABA}}$ measured in VP neurons seen in perforated patch recordings is not contaminated by leakage of $\mathrm{Cl}^{-}$from the patch pipette into the recorded cell. In whole-cell recordings, there was no significant difference in the $E_{\mathrm{GABA}}$ between putative OT and VP neurons $(-55.0 \pm 2.1$ $\mathrm{mV}, n=12$ putative OT cells; $-51.6 \pm 1.3 \mathrm{mV}, n=14 \mathrm{VP}$ cells; $p=0.166$, Mann-Whitney $U$ test) (Fig. 2C).

\section{GABA reversal potential in magnocellular neurons from wild-type rats}

Previous studies have shown that GFP expression does not affect the intracellular $\mathrm{Cl}^{-}$concentration or $E_{\mathrm{GABA}}$ (Kuner and Augustine, 2000; DeFazio et al., 2002; Fu and van den Pol, 2007), and that the expression of VP in the VP-eGFP transgenic rats is not significantly different from that in wild-type rats (Fujio et al., 2006). To confirm that the positive $E_{\mathrm{GABA}}$ in VP-eGFPexpressing cells was not a result of the GFP expression or the genetic changes in the VP neurons, we determined the $E_{\mathrm{GABA}}$ in magnocellular neurons from the SON and PVN of age-matched wild-type male Wistar rats. Consistent with the data from the VP-eGFP transgenic rats, the measured values of $E_{\mathrm{GABA}}$ in magnocellular neurons from wild-type rats distributed into two groups, one group with an $E_{\mathrm{GABA}}$ negative to the resting membrane potential $(-75.4 \pm 3.8 \mathrm{mV} \mathrm{mV}, n=6)$ and the other group with an $E_{\mathrm{GABA}}$ positive to the resting potential $(-37.2 \pm 2.6 \mathrm{mV}$, $n=11$ ) (Fig. $3 A, B$ ). The cells assigned to each of the two groups on the basis of their $E_{\mathrm{GABA}}$ were tested for membrane properties characteristic of OT or VP neurons. There was a significant difference in the rectification index, defined as $\left(\mathrm{I}_{-45} \mathrm{mv}-\right.$ $\left.\mathrm{I}_{-85 \mathrm{mV}}\right) /\left(\mathrm{I}_{-85 \mathrm{mV}}-\mathrm{I}_{-125} \mathrm{mV}\right)$, between the two cell groups $(0.40 \pm 0.04$ in cells with outward GABA currents at resting membrane potential, $n=8 ; 0.83 \pm 0.04$ in cells with inward GABA currents at resting membrane potential, $n=20, p<0.001$, Student's $t$ test) (Fig. $3 C$ ). Thus, the cells that showed a negative $E_{\mathrm{GABA}}$ generated a hyperpolarization-induced inward rectification, which is manifested as a non-linearity in the membrane potential range between $-85 \mathrm{mV}$ and $-125 \mathrm{mV}$ and is characteristic of OT, but not VP, neurons (Hirasawa et al., 2003) (Fig. $3 D)$. The cells that showed a positive $E_{\mathrm{GABA}}$ had a linear or nearlinear $I-V$ relationship, which is characteristic of VP neurons (Fig. 3E). Additionally, the cells with a hyperpolarized $E_{\mathrm{GABA}}$ were found in the ventromedial part of the PVN and the dorsolateral part of the SON, where OT neurons are concentrated, while the cells with a depolarized $E_{\mathrm{GABA}}$ were found in the dorsolateral part of the PVN and in the ventromedial part of the SON, where VP neurons are concentrated (data not shown) (Kanaka et al., 2001; Kawasaki et al., 2006; Simmons and Swanson, 2009).

Finally, to confirm the identity of the two populations of magnocellular neurons in wild-type rats as oxytocinergic and vasopressinergic, following characterization of synaptic GABA currents with perforated-patch recordings, we labeled neurons by including biocytin in the patch solution and infusing biocytin intracellularly by rupturing the membrane at the end of recordings to achieve the whole-cell configuration. After recording and injecting one or two neurons in a slice, the slice was processed for immunohistochemistry using antibodies against OT and VP (see Materials and Methods). Of 16 neurons that generated inward spontaneous synaptic currents at resting membrane potential (with glutamate receptors blocked), 15 stained positively for
VP and negatively for OT (Fig. 3F, top); of three neurons that generated outward spontaneous synaptic currents at resting potential, two stained positively for OT and negatively for VP (Fig. $3 F$, bottom). Together, these results in slices from wild-type rats confirmed our findings in VP-eGFP rats of a positive $E_{\mathrm{GABA}}$ in VP neurons and a negative $E_{\mathrm{GABA}}$ in OT neurons.

\section{GABA excites vasopressinergic magnocellular neurons}

To determine whether depolarizing GABA synaptic currents in VP neurons are excitatory and can trigger action potentials, cells were recorded in the perforated patch mode and were held at a membrane potential close to spike threshold, where spontaneous action potential currents were often observed. At this potential, spontaneous inward GABA currents were observed, indicating that GABA is excitatory near spike threshold. In addition, extracellular electrical stimulation elicited inward synaptic GABA currents, which often triggered action potential currents (Fig. $4 A$ ). In current-clamp mode, VP neurons held near spike threshold in the presence of ionotropic glutamate receptor antagonists showed spontaneous GABAmediated depolarizing synaptic potentials that were often followed by action potential firing (Fig. $4 \mathrm{~B}$ ).

We next examined whether basal GABA levels have an excitatory effect on spontaneous spiking activity in VP cells. To record spiking activity without influencing the $E_{\mathrm{GABA}}$, we performed extracellular loose-seal cell-attached patch recordings, which allow the plasma membrane at the patch to remain intact and thus the recorded cell to maintain its intracellular $\mathrm{Cl}^{-}$concentration. This provides an accurate measurement of spontaneous firing activity with minimal influence of the recording conditions (Nunemaker et al., 2003; Perkins, 2006). The frequency of spontaneous spiking activity in VP neurons recorded in the loose-seal mode was significantly reduced by bath application of the $\mathrm{GABA}_{\mathrm{A}}$ receptor antagonist bicuculline methiodide $(10 \mu \mathrm{M})$ (from $1.34 \pm 0.50 \mathrm{~Hz}$ to $0.64 \pm 0.32 \mathrm{~Hz}, n=7, p<0.05$, Wilcoxon signed-rank test) (Fig. 4C,D), suggesting that tonic GABA release has an excitatory influence on spontaneous spike generation in $\mathrm{VP}$ neurons. Blocking $\mathrm{GABA}_{\mathrm{A}}$ receptor activity had the opposite effect on spiking activity in GFP-negative, putative OT neurons. Thus, bicuculline $(10 \mu \mathrm{M})$ caused a significant increase in the firing frequency of GFP-negative cells (from $0.69 \pm 0.71 \mathrm{~Hz}$ to $1.60 \pm 0.63 \mathrm{~Hz}, n=6, p<0.05$, Wilcoxon signed-rank test) (Fig. $4 C, D$ ), indicating that GABA acts basally to inhibit spiking in OT neurons. Interestingly, the average basal spike frequency in VP neurons was significantly greater than that of OT neurons $(1.55 \pm 0.36$ in VP neurons, $n=25$, vs $0.52 \pm 0.30 \mathrm{~Hz}$ in OT neurons, $n=11$, Mann-Whitney $U$ test, $p<0.01$ ) (Fig. $4 E$ ), and decreased to below the spike frequency of OT neurons when $\mathrm{GABA}_{\mathrm{A}}$ receptors in both cell types were blocked $(0.64 \pm 0.32 \mathrm{~Hz}$ in VP neurons vs $1.60 \pm 0.63 \mathrm{~Hz}$ in OT neurons).

\section{Differential chloride transport in vasopressin and oxytocin neurons}

Previous immunohistochemical studies have shown a relative paucity of expression of the KCC2 cotransporter in hypothalamic VP neurons (Kanaka et al., 2001; Belenky et al., 2010). Our immunohistochemistry findings showed strong KCC2 immunolabeling in the hypothalamic areas surrounding the SON and PVN, but relatively weaker labeling in the SON and PVN (Fig. 5A). Some labeling was seen in GFP-negative, putative OT neurons, but no KCC2 immunolabeling was seen in GFP-positive VP neurons (Fig. 5A), suggesting a relative lack of KCC2 expression in GFP-positive VP neurons. The KCC2 labeling that was seen in 

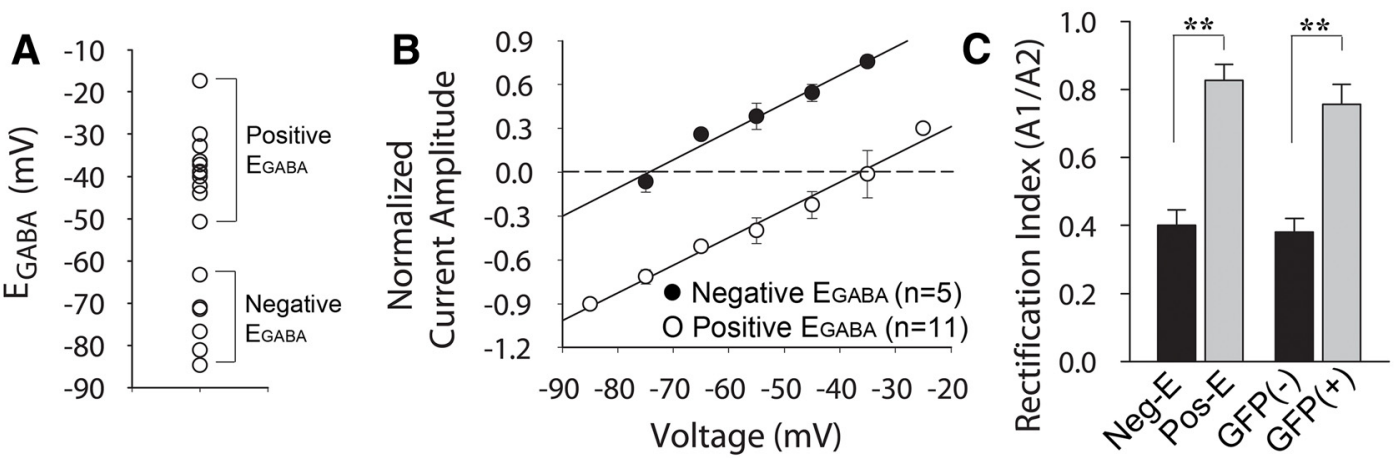

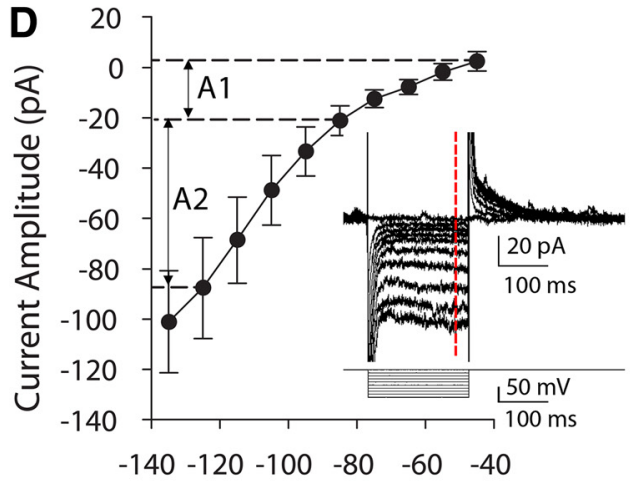

Membrane Potential ( $\mathrm{mV}$ )
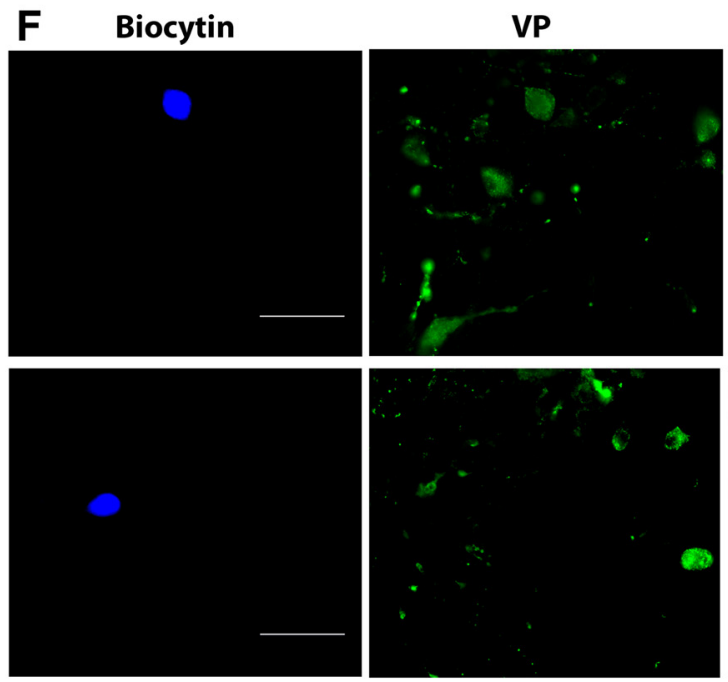

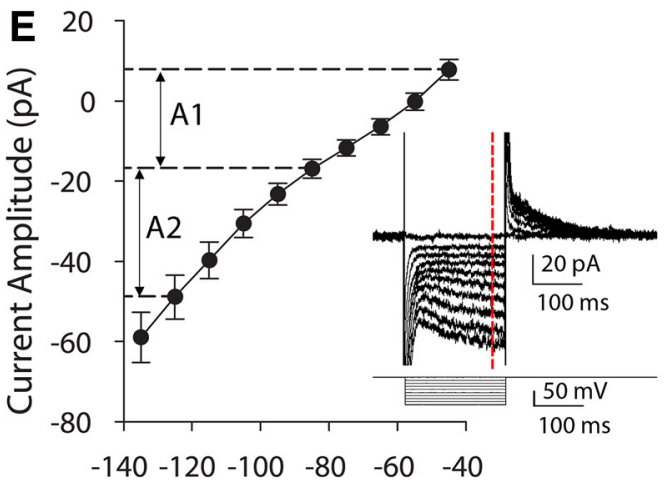

Membrane Potential ( $\mathrm{mV})$
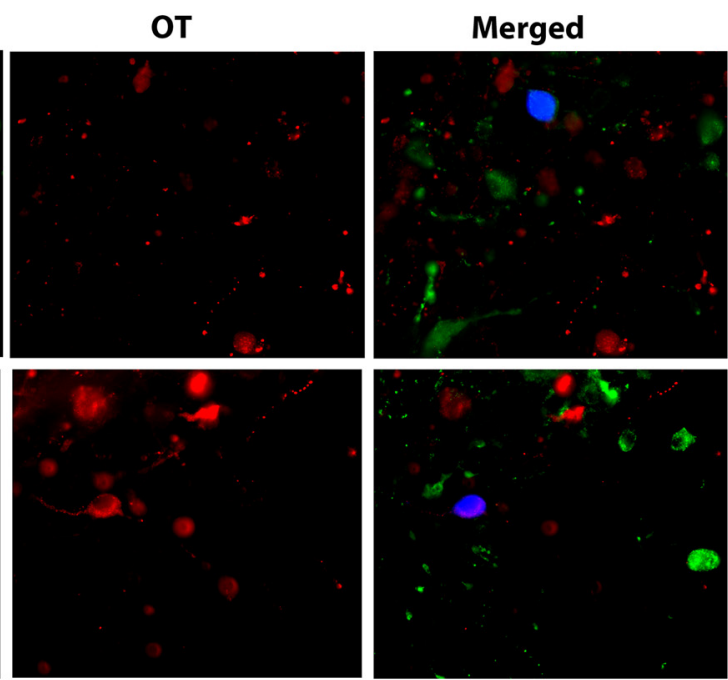

Figure 3. $E_{\mathrm{GABA}}$ in magnocellular neurons from wild-type rats. $A$, Scatter plot showing mean $E_{\mathrm{GABA}}$ values measured in unidentified magnocellular neurons ( $n=16$ ) from wild-type rats. The $E_{\mathrm{GABA}}$ values distribute into two distinct groups, one with values of $E_{\mathrm{GABA}}$ more negative than the resting membrane potential (Negative $E_{\mathrm{GABA}}, n=6$ ) and the other with values of $E_{\mathrm{GABA}}$ more positive than the resting membrane potential (Positive $E_{\mathrm{GABA}}, n=11$ ). $\boldsymbol{B}$, Evoked synaptic GABA current amplitudes plotted against holding potentials in the cells shown in $\boldsymbol{A}$ divided into two groups, negative- $E_{\mathrm{GABA}}$ and positive- $E_{\mathrm{GABA}}$. $C$, Average rectification index from the negative- $E_{\mathrm{GABA}}$ (Neg- $E$ ) and positive- $E_{\mathrm{GABA}}$ groups (Pos- $E$ ) of unidentified magnocellular neurons recorded in slices from wild-type rats (negative- $E_{\mathrm{GABA}}, n=8$; positive- $E_{\mathrm{GABA}}, n=20, p<0.01$ ) (left). Average rectification index from the GFP-negative and GFP-positive magnocellular neurons recorded in slices from VP-GFP rats (GFP-negative, $n=5$; GFP-positive $n=9, p<0.01$ ) (right). A1: Rectification measured between voltage steps of $-45 \mathrm{mV}$ and $-85 \mathrm{mV}$; $\mathrm{A2}$ : rectification measured between voltage steps of $-125 \mathrm{mV}$ and $-85 \mathrm{mV}$ (shown in $\boldsymbol{D}$ and $\boldsymbol{E}$ ); ${ }^{* *} p<0.01$. $\boldsymbol{D}$, (ells with outward currents at resting membrane potential showed a nonlinear $I-V$ relationship $(n=8)$. Membrane currents were elicited by a series of voltage steps from a holding potential of $-45 \mathrm{mV}$ (inset). The current measurements in the $I-V$ plot were obtained from values averaged over $10 \mathrm{~ms}$ at the end of the voltage steps (dashed red line). $\boldsymbol{E}$, Cells with inward currents at resting membrane potential showed a linear $/-V$ relationship generated with a series of voltage steps from a holding potential of -45 $\mathrm{mV}(n=20)$ (inset). $\boldsymbol{F}$, Representative biocytin-labeled, immunohistochemically identified magnocellular neurons from wild-type rats that generated inward synaptic GABA currents (top) and outward synaptic GABA currents (bottom) at resting membrane potential. The magnocellular neuron that generated inward synaptic currents (blue, top) at resting potential was immunopositive for vasopressin (green, top) and negative for OT (red, top), identifying it as a VP-expressing neuron. The magnocellular neuron that generated outward synaptic currents at resting potential (blue, bottom) was immunonegative for VP (green, bottom) and positive for OT (red, bottom), identifying it as an 0T-expressing neuron. Scale bars: $50 \mu \mathrm{m}$.

GFP-negative, putative OT neurons appeared to reside mainly in the plasma membranes of the labeled cells (Fig. $5 A$ ).

We next tested the effects of KCC2 and NKCC1 inhibitors on $E_{\mathrm{GABA}}$ using perforated-patch recordings in GFP-positive and
GFP-negative neurons to determine whether the differential functional expression of $\mathrm{Cl}^{-}$cotransporters is responsible for the difference in $E_{\mathrm{GABA}}$ between $\mathrm{VP}$ and OT neurons. In putative OT neurons, pharmacological inhibition of KCC2 by preincubation 
A

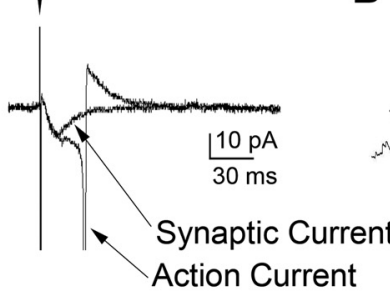

C

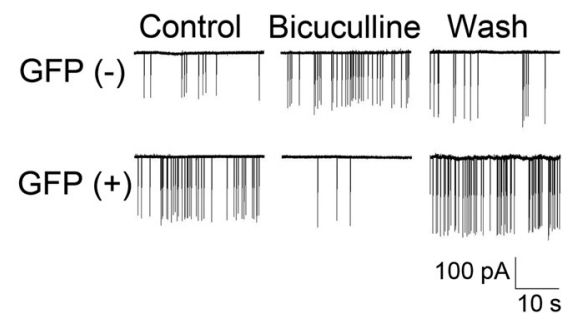

B

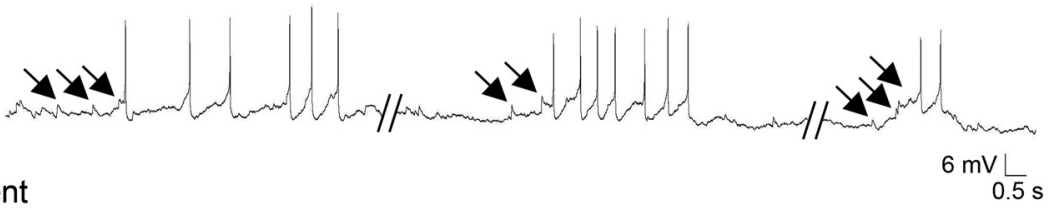

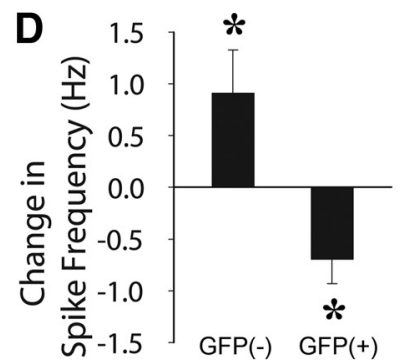

E

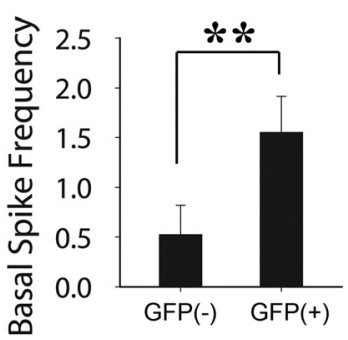

Figure 4. Synaptic GABA signals cause action potential generation in VP cells. $\boldsymbol{A}$, Two superimposed synaptic responses to electrical stimulation (filled arrowhead) that straddled threshold, producing a subthreshold inward synaptic current to the first stimulus and an action potential current to the second stimulus. Evoked synaptic $G A B A$ currents often induced action potential currents. $\boldsymbol{B}$, In current-clamp recordings, spontaneous depolarizing GABA synaptic potentials (black arrows) were observed and were often followed by action potentials. $\boldsymbol{C}$, Effect of blocking GABA currents on spontaneous firing activity recorded with the loose-patch technique. Bath application of bicuculline (10 $\mu \mathrm{m}$ ) caused an increase in spike frequency in a GFP-negative cell and a decrease in spike frequency in a GFP-positive cell. $\boldsymbol{D}$, Average change in spike frequency caused by bicuculline $(10 \mu \mathrm{M})$ in GFP-negative cells $(n=6)$ and GFP-positive cells $\left(n=7\right.$; $\left.{ }^{*} p<0.05\right)$. $E$, Basal spike frequency (in Hz) in GFP-negative $(n=11)$ and GFP-positive cells $(n=25) ;{ }^{* *} p<0.01$.

of slices in VU0240551 (75 $\mu \mathrm{M})$ for $\geq 30$ min caused a positive shift in $E_{\mathrm{GABA}}$, from $-75.1 \pm 2.4 \mathrm{mV}$ in control $(n=9)$ to $-61.0 \pm 2.8 \mathrm{mV}$ in VU0240551 $(n=6)(p<0.01$, Student's $t$ test) (Fig. $5 B, C$ ), indicating that $\mathrm{KCC} 2$ contributes to lowering the intracellular $\mathrm{Cl}^{-}$concentration in these cells. In whole-cell recordings, $E_{\mathrm{GABA}}$ in putative OT neurons was not affected by VU0240551 (control $=-55.0 \pm 3.1 \mathrm{mV}, n=8$; in VU0240551 $=$ $-52.8 \pm 3.5 \mathrm{mV}, n=4$; n.s., Student's $t$ test) (data not shown), which is likely due to the fact that the intracellular $\mathrm{Cl}^{-}$concentration is mainly determined by the patch solution because of the relatively large volume of the pipette. To examine whether NKCC1 also contributes to the intracellular $\mathrm{Cl}^{-}$concentration and $E_{\mathrm{GABA}}$ in putative OT neurons, we tested the effect of the NKCC1 inhibitor bumetanide. The blockade of NKCC1 by bumetanide $(40 \mu \mathrm{M})$ had no significant effect on $E_{\mathrm{GABA}}$ in putative OT neurons (control: $-75.1 \pm 2.4 \mathrm{mV}, n=9$; in bumetanide: $77.0 \pm 3.8 \mathrm{mV}, n=6, p=0.67$, Student's $t$ test), suggesting that NKCC1 does not contribute significantly to the $E_{\mathrm{GABA}}$ in OT cells from adult hypothalamus.

Unlike in OT neurons, the KCC2 inhibitor VU0240551 (75 $\mu \mathrm{M})$ did not cause a significant change in $E_{\mathrm{GABA}}$ in VP neurons (control: $-33.1 \pm 3.4 \mathrm{mV}, n=15$; in VU0240551: $-28.2 \pm 2.5$ $\mathrm{mV}, n=9, p=0.311$, Student's $t$ test) (Fig. $5 D, E$ ), suggesting that KCC2 does not contribute significantly to intracellular $\mathrm{Cl}^{-}$ buffering and to the $E_{\mathrm{GABA}}$ in VP neurons. Previous studies have shown that bumetanide is a specific inhibitor of NKCC1 at a low concentration $(\sim 10 \mu \mathrm{M})$, but it can also inhibit the KCC family of transporters at higher concentrations (Russell, 2000; Kahle et al., 2008). In our experiments, bath application of $20 \mu \mathrm{M}$ bumetanide caused a negative shift in $E_{\mathrm{GABA}}$ in VP cells, but it did not reach significance (control: $-33.1 \pm 3.4 \mathrm{mV}, n=15$; bumetanide: $44.7 \pm 5.3 \mathrm{mV}, n=9 ; p=0.066$, Student's $t$ test) (data not shown); however, $40 \mu \mathrm{M}$ bumetanide caused a significant negative shift in $E_{\mathrm{GABA}}$ (control: $-33.1 \pm 3.4 \mathrm{mV}, n=15$; bumetanide: $-55.7 \pm 2.2 \mathrm{mV}, n=8, p<0.05$, Student's $t$ test) (Fig. $5 D, E)$. The change in $E_{\mathrm{GABA}}$ in VP cells by bumetanide is unlikely to be due to a nonselective inhibition of KCC2 since we found no change in $E_{\mathrm{GABA}}$ with the selective KCC2 inhibitor VU0240551. These findings together indicate that the presence of NKCC1 and the absence of KCC2 in VP neurons combine to establish the depolarized $E_{\mathrm{GABA}}$, and that the hyperpolarized $E_{\mathrm{GABA}}$ in OT neurons is established by KCC2.

\section{Discussion}

Here, we demonstrate that GABA is excitatory in vasopressinergic magnocellular neurons of the adult SON and PVN. This finding is of critical importance for the control of VP release and the regulation of fluid homeostasis, given that GABA synapses constitute $\sim 60 \%$ of all synapses on the magnocellular neurons (Theodosis et al., 1986; Decavel and Van den Pol, 1990), and GABA is, therefore, a predominant neurotransmitter in the SON and magnocellular PVN. The sources of the GABAergic inputs to VP neurons are likely to be the hypothalamic area dorsal to the optic chiasm, the dorsomedial hypothalamic nucleus, and/or the perinuclear areas surrounding the PVN and SON (Decavel and Van den Pol, 1990; Thellier et al., 1994; Vrang et al., 1995; Boudaba et al., 1996; Boudaba et al., 1997). Most of the nonGABAergic synaptic profiles on magnocellular neurons in the PVN and SON are glutamatergic and noradrenergic (El Majdoubi et al., 1997; Michaloudi et al., 1997), both of which are predominantly excitatory (Randle et al., 1986a; Wuarin and Dudek, 1993; Boudaba et al., 2003), which challenges the longheld concept of an inhibitory-excitatory synaptic balance that controls excitability in VP neurons. Either VP neurons are not under a counterbalanced excitatory-inhibitory synaptic regulation, or another inhibitory mechanism compensates for the absence of GABAergic inhibition.

\section{How can GABA be excitatory in VP neurons?}

This finding runs contrary to those of previous in vitro and in vivo studies that defined GABA as an inhibitory neurotransmitter in the magnocellular neuroendocrine system, a discrepancy that may have several sources. First, previous in vitro electrophysiological studies used intracellular recordings, ei- 
A
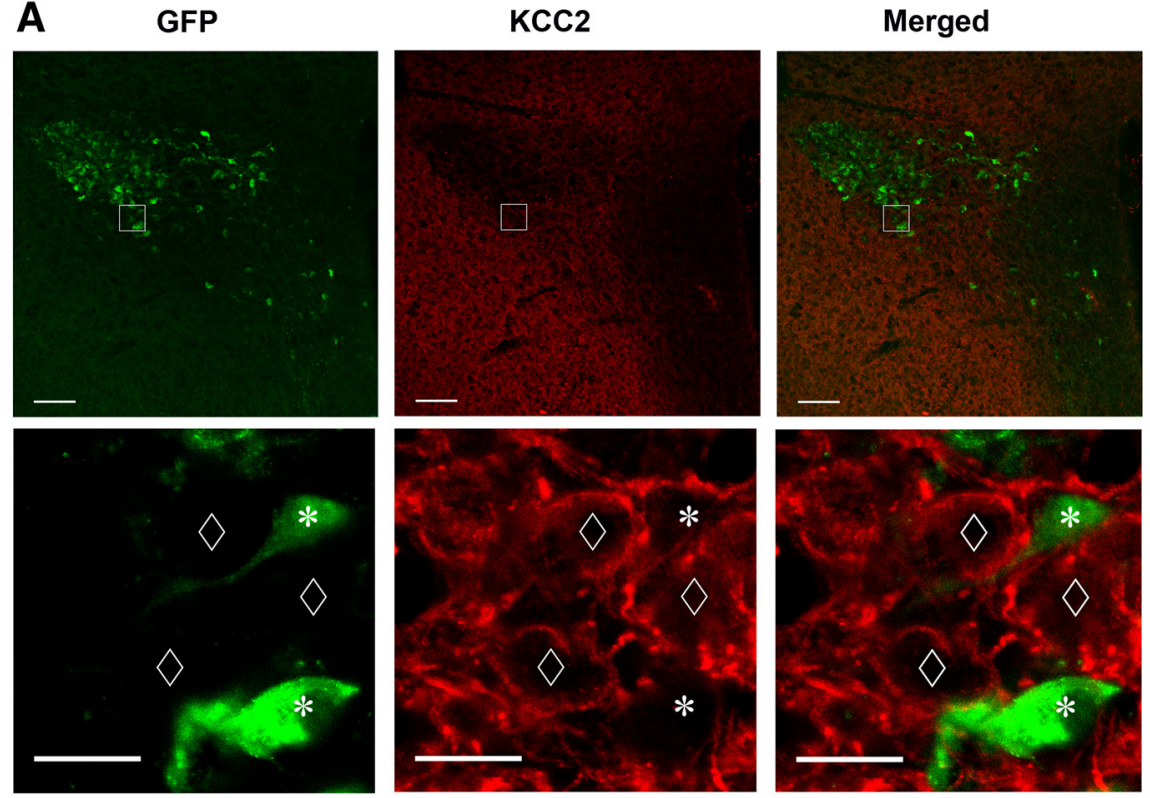

B
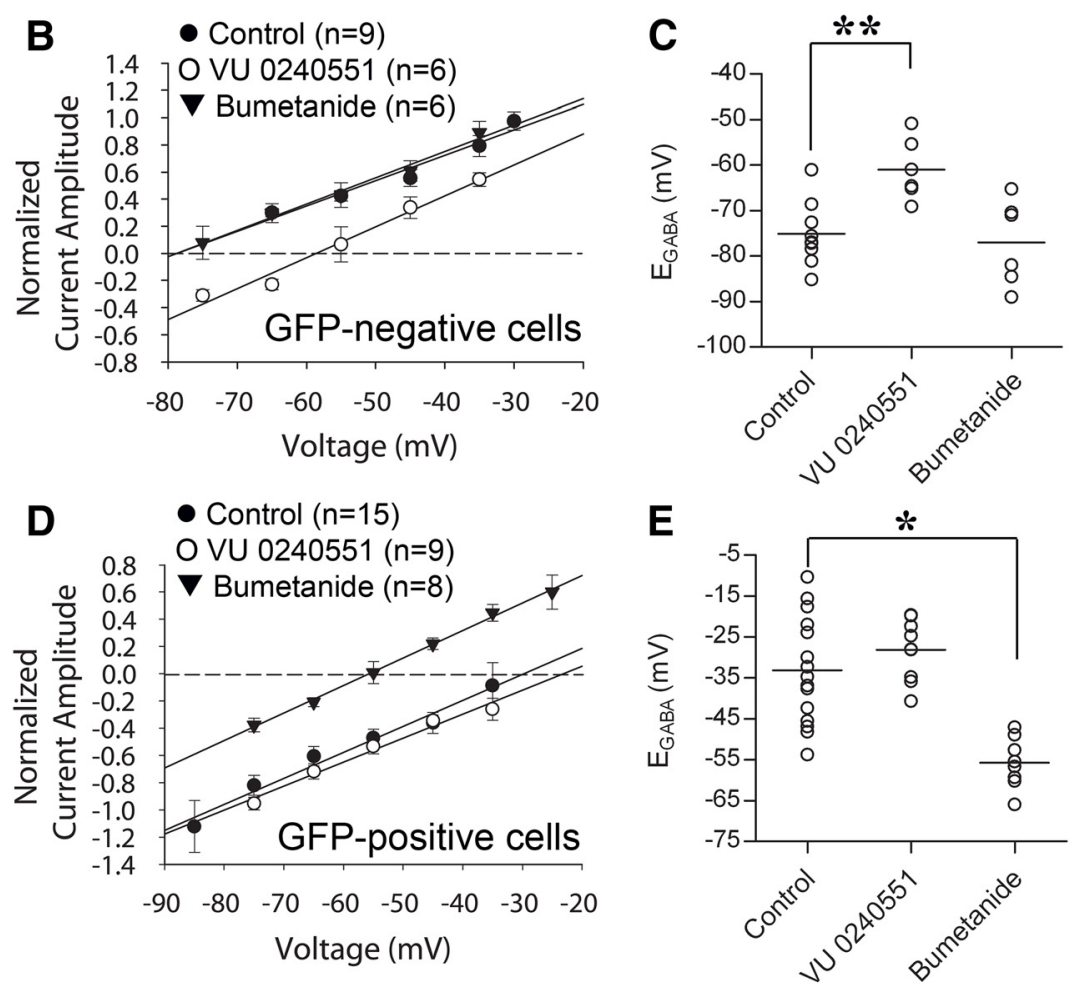

Figure 5. Differential expression of $\mathrm{Cl}^{-}$cotransporters determines $E_{\mathrm{GABA}} \cdot A$, Confocal images showing the expression of VP-eGFP (left) and KCC2 (middle) in a section of the PVN and surrounding area. At low magnification (top), the medial PVN and the area surrounding the PVN display relatively strong immunostaining, whereas the lateral magnocellular region of the PVN shows a relative paucity of immunostaining for KCC2. At higher magnification (bottom), the GFP-positive, VP neurons are immunonegative for KCC2 (asterisks), while there is strong KCC2 expression in GFP-negative cells (diamonds). $B, I-V$ plot showing a positive shift in $E_{\text {GABA }}$ in GFP-negative, putative 0T cells $(n=6)$ caused by the $K C C 2$ antagonist VU $0240551(75 \mu \mathrm{m})$. The NKCC1 inhibitor bumetanide $(40 \mu \mathrm{m})$ had no significant effect on $E_{\mathrm{GABA}}$ in GFP-negative cells $(n=6)$. C, A scatter plot showing changes in $E_{\text {GABA }}$ in GFP-negative, putative $0 T$ cells caused by VU 0240551 and bumetanide; ${ }^{* *} p<0.01$. D, I-V plot showing a negative shift in $E_{G A B A}$ in VP cells caused by the NKKC1 inhibitor bumetanide $(40 \mathrm{~mm}, n=$ 8). The KCC2 inhibitor VU $0240551(75 \mu \mathrm{m})$ had no effect on $E_{\text {GABA }}(n=9)$ in GFP-positive cells. $E$, A scatter plot showing changes in $E_{\text {GABA }}$ in VP cells caused by VU 0240551 and bumetanide. Scale bars: $A$, top, $100 \mu \mathrm{m} ; A$, bottom, $20 \mu \mathrm{m} ;{ }^{*} p<0.05,{ }^{\#} p<0.01$.

ther sharp-electrode or whole-cell patch-clamp recordings, to study GABAergic synaptic inputs to VP cells (Randle et al., 1986b; Tasker and Dudek, 1993; Wuarin and Dudek, 1993; Boudaba et al., 1996; Stern and Ludwig, 2001). Both sharp electrodes and patch electrodes alter the intracellular $\left[\mathrm{Cl}^{-}\right]$and artificially shift $E_{\mathrm{GABA}}$, even without high $\left[\mathrm{Cl}^{-}\right]$in the electrode, as we show here with transition of the patchclamp configuration from perforated-patch to whole-cell. Similar shifts in $E_{\mathrm{GABA}}$ have been seen with sharp electrodes containing high $\left[\mathrm{Cl}^{-}\right]$(Randle et al., 1986b; Boudaba et al., 1996), which indicates that sharp microelectrodes also clamp the intracellular $\left[\mathrm{Cl}^{-}\right]$. Second, previous in vivo studies determined GABAergic afferent inputs to magnocellular VP neurons to be inhibitory largely based on local microinjection of $\mathrm{GABA}_{\mathrm{A}}$ analogs into the SON and PVN (Jhamandas and Renaud, 1986; Nissen and Renaud, 1994). Even highly localized intracranial injections in vivo are subject to diffusion to local presynaptic interneurons, since these neurons can be in close proximity to the target neurons. The SON and PVN receive inputs from local glutamatergic interneurons located within the PVN (Daftary et al., 2000) and from glutamatergic and GABAergic interneurons in perinuclear regions (Boudaba et al., 1997; Wuarin, 1997), all of which may have a negative $E_{\mathrm{GABA}}$. Indeed, anatomical and electrophysiological studies suggest that afferent projections from the diagonal band of Broca and the median preoptic nucleus, structures that inhibit vasopressin release (Jhamandas and Renaud, 1986; Nissen and Renaud, 1994), relay through inhibitory interneurons proximal to the SON (Hatton et al., 1983; Tribollet et al., 1985; Jhamandas et al., 1989; Nissen et al., 1993). Finally, previous studies with GABA agonists often used relatively high concentrations of exogenous agonist (Ludwig and Leng, 2000), which, based on our findings, should cause a robust membrane depolarization and could lead to the suppression of firing due to sodium channel inactivation. A high concentration of exogenous GABA agonist, therefore, may have the opposite effect to that of synaptically released GABA.

\section{Excitatory actions of GABA}

Despite the general rule that GABA actions at $\mathrm{GABA}_{\mathrm{A}}$ receptors are inhibitory, GABA also has been shown to be excitatory in some neurons under different conditions. For example, the excitatory nature of GABA in developing neural circuits, though not without controversy (Rheims et al., 2009; Holmgren et al., 2010), is well documented, and a physiological role of excitatory GABA actions during neuronal development has been proposed (Chen et al., 1996; Ben-Ari, 2001; Gao and van den Pol, 2001; Represa and Ben-Ari, 2005; Sipilä et al., 2009). GABA has also been shown to be excitatory in more mature animals, for example, in the hip- 
pocampus, cortex, amygdala, and basal ganglia (Golding and Oertel, 1996; Martina et al., 2001; Chavas and Marty, 2003; Gulledge and Stuart, 2003; Woodruff et al., 2006; Viitanen et al., 2010), although these findings were from immature neurons since the studies were conducted in rodents aged 5 weeks or younger, which leaves open the question of whether the excitatory-to-inhibitory switch in these neurons may occur with puberty. GABA has also been shown to be excitatory in mature animals under specific conditions, such as during phases of the circadian cycle (Wagner et al., 1997; De Jeu and Pennartz, 2002; Choi et al., 2008), in areas where neurogenesis occurs (Tozuka et al., 2005), and during stress (Hewitt et al., 2009; Kim et al., 2011). GABA's excitatory actions are important in the adult brain not only for the regulation of excitability, but also for synapse formation and synaptic integration (Albus et al., 2005; Tozuka et al., 2005; Ge et al., 2006), and depend on a number of factors, including GABA channel conductance, cellular compartment, cell type, and basal neuronal activity (DeFazio et al., 2002; Han et al., 2002; Moenter and DeFazio, 2005; Fu and van den Pol, 2007; Herbison and Moenter, 2011; Song et al., 2011).

The excitatory influence of GABA and the capacity of GABA to drive spike firing in VP cells is quite robust compared with that reported in most other brain areas (Golding and Oertel, 1996; Bracci and Panzeri, 2006; Woodruff et al., 2009), where often the depolarizing GABA signals maintain their inhibitory influence due to shunting (Randle and Renaud, 1987; Zhang and Jackson, 1993; Hewitt et al., 2009). The physiological significance of the excitatory GABA input to VP neurons in the PVN and SON is not yet clear, although the robust suppression of spiking activity in $\mathrm{VP}$ neurons by blocking $\mathrm{GABA}_{\mathrm{A}}$ receptors suggests that the excitatory GABAergic input contributes to the higher firing frequency of VP neurons relative to OT neurons (Armstrong et al., 1994). Oxytocin neurons increased their firing frequency significantly under $\mathrm{GABA}_{\mathrm{A}}$ receptor blockade, which indicates a robust tonic inhibitory GABAergic input to OT cells (Li et al., 2007; Popescu et al., 2010) and suggests that the tonic synaptic GABA input to the two cell types largely determines their spontaneous spiking activity under these recording conditions.

A recent study showed that chronic osmotic stress induces a positive shift in $E_{\mathrm{GABA}}$ in unidentified magnocellular neurons, making synaptic GABA inputs excitatory (Kim et al., 2011). In that study, GABA was inhibitory in $75 \%$ and excitatory in $25 \%$ of unidentified magnocellular neurons from control animals. Our findings suggest that the excitatory GABA inputs in that study were in VP neurons, and that the shift in $E_{\mathrm{GABA}}$ with salt-loading was specific, therefore, to the OT neurons. Another study also reported depolarizing GABA responses in magnocellular neurons, also in a subset of recorded cells that may have been VP neurons (Randle and Renaud, 1987).

\section{Differential expression of chloride cotransporters}

Consistent with our immunohistochemical confirmation of a lack of KCC2 expression in VP neurons (Kanaka et al., 2001; Belenky et al., 2008), inhibition of KCC2 activity had no effect on $E_{\mathrm{GABA}}$ in VP neurons, but shifted $E_{\mathrm{GABA}}$ positive in OT neurons. Blockade of NKCC1, on the other hand, caused a significant negative shift of $E_{\mathrm{GABA}}$ in VP neurons, but had no effect in OT neurons, suggesting that NKCC1 accumulates intracellular chloride in VP cells, but not in OT cells. The lack of KCC2 expression found in VP neurons in perfused brain tissue suggests that the shift in chloride gradient that we observed in vitro is present in vivo, and that it was not, therefore, the result of disrupted chlo- ride transport induced selectively in VP neurons by the slicing procedure.

\section{Mechanisms that control the excitability of vasopressin neurons}

Our demonstration that GABA is excitatory in VP neurons raises the question of how the excitability of VP neurons is controlled, if neither of the two main neurotransmitters, glutamate and GABA, is inhibitory. A complete loss of synaptic inhibition would be expected to render the cells hyperexcitable, and implies that other inhibitory inputs may take the place of GABA synapses on VP neurons to maintain appropriate levels of excitability. Further studies are required to determine whether other neurotransmitters or gliotransmitters are responsible for providing an inhibitory input to VP neurons to counter the glutamate and GABA excitatory synaptic inputs.

Thus, GABAergic synaptic inputs to VP neurons, and to OT neurons under some conditions, contribute to the excitatory synaptic control of the hypothalamic-neurohypophysial system. It remains to be determined how this control integrates into a broader regulation of the excitability and activation of the hypothalamic magnocellular neurons, how plastic this control is under different physiological conditions, and what the molecular mechanisms are that are responsible for causing the positive shift in $E_{\mathrm{GABA}}$ in vasopressinergic neuroendocrine cells.

\section{References}

Albus H, Vansteensel MJ, Michel S, Block GD, Meijer JH (2005) A GABAergic mechanism is necessary for coupling dissociable ventral and dorsal regional oscillators within the circadian clock. Curr Biol 15:886-893.

Armstrong WE, Smith BN, Tian M (1994) Electrophysiological characteristics of immunochemically identified rat oxytocin and vasopressin neurones in vitro. J Physiol 475:115-128.

Belenky MA, Yarom Y, Pickard GE (2008) Heterogeneous expression of gamma-aminobutyric acid and gamma-aminobutyric acid-associated receptors and transporters in the rat suprachiasmatic nucleus. J Comp Neurol 506:708-732.

Belenky MA, Sollars PJ, Mount DB, Alper SL, Yarom Y, Pickard GE (2010) Cell-type specific distribution of chloride transporters in the rat suprachiasmatic nucleus. Neuroscience 165:1519-1537.

Ben-Ari Y (2001) Developing networks play a similar melody. Trends Neurosci 24:353-360.

Ben-Barak Y, Russell JT, Whitnall MH, Ozato K, Gainer H (1985) Neurophysin in the hypothalamo-neurohypophysial system. I. Production and characterization of monoclonal antibodies. J Neurosci 5:81-97.

Boudaba C, Szab ó K, Tasker JG (1996) Physiological mapping of local inhibitory inputs to the hypothalamic paraventricular nucleus. J Neurosci 16:7151-7160.

Boudaba C, Schrader LA, Tasker JG (1997) Physiological evidence for local excitatory synaptic circuits in the rat hypothalamus. J Neurophysiol 77:3396-3400.

Boudaba C, Di S, Tasker JG (2003) Presynaptic noradrenergic regulation of glutamate inputs to hypothalamic magnocellular neurones. J Neuroendocrinol 15:803-810.

Bracci E, Panzeri S (2006) Excitatory GABAergic effects in striatal projection neurons. J Neurophysiol 95:1285-1290.

Chavas J, Marty A (2003) Coexistence of excitatory and inhibitory GABA synapses in the cerebellar interneuron network. J Neurosci 23:2019-2031.

Chen G, Trombley PQ, van den Pol AN (1996) Excitatory actions of GABA in developing rat hypothalamic neurones. J Physiol 494:451-464.

Choi HJ, Lee CJ, Schroeder A, Kim YS, Jung SH, Kim JS, Kim do Y, Son EJ, Han HC, Hong SK, Colwell CS, Kim YI (2008) Excitatory actions of GABA in the suprachiasmatic nucleus. J Neurosci 28:5450-5459.

Cordero-Erausquin M, Coull JA, Boudreau D, Rolland M, De Koninck Y (2005) Differential maturation of GABA action and anion reversal potential in spinal lamina I neurons: impact of chloride extrusion capacity. J Neurosci 25:9613-9623.

Daftary SS, Boudaba C, Tasker JG (2000) Noradrenergic regulation of par- 
vocellular neurons in the rat hypothalamic paraventricular nucleus. Neuroscience 96:743-751.

Decavel C, Van den Pol AN (1990) GABA: a dominant neurotransmitter in the hypothalamus. J Comp Neurol 302:1019-1037.

DeFazio RA, Heger S, Ojeda SR, Moenter SM (2002) Activation of A-type gamma-aminobutyric acid receptors excites gonadotropin-releasing hormone neurons. Mol Endocrinol 16:2872-2891.

De Jeu M, Pennartz C (2002) Circadian modulation of GABA function in the rat suprachiasmatic nucleus: excitatory effects during the night phase. J Neurophysiol 87:834-844.

Dreifuss JJ, Kalnins I, Kelly JS, Ruf KB (1971) Action potentials and release of neurohypophysial hormones in vitro. J Physiol 215:805-817.

Dutton A, Dyball RE (1979) Phasic firing enhances vasopressin release from the rat neurohypophysis. J Physiol 290:433-440.

El Majdoubi M, Poulain DA, Theodosis DT (1997) Lactation-induced plasticity in the supraoptic nucleus augments axodendritic and axosomatic GABAergic and glutamatergic synapses: an ultrastructural analysis using the disector method. Neuroscience 80:1137-1147.

Engelmann M, Bull PM, Brown CH, Landgraf R, Horn TF, Singewald N, Ludwig M, Wotjak CT (2004) GABA selectively controls the secretory activity of oxytocin neurons in the rat supraoptic nucleus. Eur J Neurosci 19:601-608.

Fiumelli H, Cancedda L, Poo MM (2005) Modulation of GABAergic transmission by activity via postsynaptic $\mathrm{Ca}^{2+}$-dependent regulation of KCC2 function. Neuron 48:773-786.

Fu LY, van den Pol AN (2007) GABA excitation in mouse hilar neuropeptide Y neurons. J Physiol 579:445-464.

Fujio T, Fujihara H, Shibata M, Yamada S, Onaka T, Tanaka K, Morita H, Dayanithi G, Kawata M, Murphy D, Ueta Y (2006) Exaggerated response of arginine vasopressin-enhanced green fluorescent protein fusion gene to salt loading without disturbance of body fluid homeostasis in rats. J Neuroendocrinol 18:776-785.

Gao XB, van den Pol AN (2001) GABA, not glutamate, a primary transmitter driving action potentials in developing hypothalamic neurons. J Neurophysiol 85:425-434.

Ge S, Goh EL, Sailor KA, Kitabatake Y, Ming GL, Song H (2006) GABA regulates synaptic integration of newly generated neurons in the adult brain. Nature 439:589-593.

Golding NL, Oertel D (1996) Context-dependent synaptic action of glycinergic and GABAergic inputs in the dorsal cochlear nucleus. J Neurosci 16:2208-2219.

Gulledge AT, Stuart GJ (2003) Excitatory actions of GABA in the cortex. Neuron 37:299-309.

Han SK, Abraham IM, Herbison AE (2002) Effect of GABA on GnRH neurons switches from depolarization to hyperpolarization at puberty in the female mouse. Endocrinology 143:1459-1466.

Hatton GI, Ho YW, Mason WT (1983) Synaptic activation of phasic bursting in rat supraoptic nucleus neurones recorded in hypothalamic slices. J Physiol 345:297-317.

Herbison AE, Moenter SM (2011) Depolarising and hyperpolarising actions of $\mathrm{GABA}(\mathrm{A})$ receptor activation on gonadotrophin-releasing hormone neurones: towards an emerging consensus. J Neuroendocrinol 23:557-569.

Hewitt SA, Wamsteeker JI, Kurz EU, Bains JS (2009) Altered chloride homeostasis removes synaptic inhibitory constraint of the stress axis. Nat Neurosci 12:438-443.

Hirasawa M, Mouginot D, Kozoriz MG, Kombian SB, Pittman QJ (2003) Vasopressin differentially modulates non-NMDA receptors in vasopressin and oxytocin neurons in the supraoptic nucleus. J Neurosci 23:4270-4277.

Holmgren CD, Mukhtarov M, Malkov AE, Popova IY, Bregestovski P, Zilberter Y (2010) Energy substrate availability as a determinant of neuronal resting potential, GABA signaling and spontaneous network activity in the neonatal cortex in vitro. J Neurochem 112:900-912.

Jhamandas JH, Renaud LP (1986) A gamma-aminobutyric-acid-mediated baroreceptor input to supraoptic vasopressin neurones in the rat. J Physiol 381:595-606.

Jhamandas JH, Raby W, Rogers J, Buijs RM, Renaud LP (1989) Diagonal band projection towards the hypothalamic supraoptic nucleus: light and electron microscopic observations in the rat. J Comp Neurol 282:15-23.

Kahle KT, Staley KJ, Nahed BV, Gamba G, Hebert SC, Lifton RP, Mount DB
(2008) Roles of the cation-chloride cotransporters in neurological disease. Nat Clin Pract Neurol 4:490-503.

Kanaka C, Ohno K, Okabe A, Kuriyama K, Itoh T, Fukuda A, Sato K (2001) The differential expression patterns of messenger RNAs encoding K-Cl cotransporters $(\mathrm{KCC} 1,2)$ and $\mathrm{Na}-\mathrm{K}-2 \mathrm{Cl}$ cotransporter $(\mathrm{NKCC} 1)$ in the rat nervous system. Neuroscience 104:933-946.

Kawasaki M, Yamaga C, Onaka T, Saito J, Mera T, Hashimoto H, Fujihara H, Okimoto N, Ohnishi H, Nakamura T, Ueta Y (2006) The short chain sugar acid, 2-buten-4-olide, activates oxytocin-secreting neurons but not arginine vasopressin-secreting neurons in the hypothalamus of rats. Brain Res 1086:133-141.

Kim JS, Kim WB, Kim YB, Lee Y, Kim YS, Shen FY, Lee SW, Park D, Choi HJ, Hur J, Park JJ, Han HC, Colwell CS, Cho YW, Kim YI (2011) Chronic hyperosmotic stress converts GABAergic inhibition into excitation in vasopressin and oxytocin neurons in the rat. J Neurosci 31:13312-13322.

Kiyama H, Emson PC (1990) Evidence for the co-expression of oxytocin and vasopressin messenger ribonucleic acids in magnocellular neurosecretory cells: simultaneous demonstration of two neurohypophysin messenger ribonucleic acids by hybridization histochemistry. J Neuroendocrinol 2:257-259.

Kuner T, Augustine GJ (2000) A genetically encoded ratiometric indicator for chloride: capturing chloride transients in cultured hippocampal neurons. Neuron 27:447-459.

Kyrozis A, Reichling DB (1995) Perforated-patch recording with gramicidin avoids artifactual changes in intracellular chloride concentration. J Neurosci Methods 57:27-35.

Li C, Tripathi PK, Armstrong WE (2007) Differences in spike train variability in rat vasopressin and oxytocin neurons and their relationship to synaptic activity. J Physiol 581:221-240.

Ludwig M, Leng G (2000) GABAergic projection from the arcuate nucleus to the supraoptic nucleus in the rat. Neurosci Lett 281:195-197.

Luther JA, Halmos KC, Tasker JG (2000) A slow transient potassium current expressed in a subset of neurosecretory neurons of the hypothalamic paraventricular nucleus. J Neurophysiol 84:1814-1825.

MacVicar BA, Andrew RD, Dudek FE, Hatton GI (1982) Synaptic inputs and action potentials of magnocellular neuropeptidergic cells: intracellular recording and staining in slices of rat hypothalamus. Brain Res Bull 8:87-93.

Martina M, Royer S, Par é D (2001) Cell-type-specific GABA responses and chloride homeostasis in the cortex and amygdala. J Neurophysiol 86:2887-2895.

Michaloudi HC, el Majdoubi M, Poulain DA, Papadopoulos GC, Theodosis DT (1997) The noradrenergic innervation of identified hypothalamic magnocellular somata and its contribution to lactation-induced synaptic plasticity. J Neuroendocrinol 9:17-23.

Misgeld U, Deisz RA, Dodt HU, Lux HD (1986) The role of chloride transport in postsynaptic inhibition of hippocampal neurons. Science 232:1413-1415.

Moenter SM, DeFazio RA (2005) Endogenous gamma-aminobutyric acid can excite gonadotropin-releasing hormone neurons. Endocrinology 146:5374-5379.

Mohr E, Bahnsen U, Kiessling C, Richter D (1988) Expression of the vasopressin and oxytocin genes in rats occurs in mutually exclusive sets of hypothalamic neurons. FEBS Lett 242:144-148.

Nissen R, Renaud LP (1994) GABA receptor mediation of median preoptic nucleus-evoked inhibition of supraoptic neurosecretory neurones in rat. J Physiol 479:207-216.

Nissen R, Cunningham JT, Renaud LP (1993) Lateral hypothalamic lesions alter baroreceptor-evoked inhibition of rat supraoptic vasopressin neurones. J Physiol 470:751-766.

Nunemaker CS, DeFazio RA, Moenter SM (2003) A targeted extracellular approach for recording long-term firing patterns of excitable cells: a practical guide. Biol Proced Online 5:53-62.

Payne JA, Stevenson TJ, Donaldson LF (1996) Molecular characterization of a putative $\mathrm{K}-\mathrm{Cl}$ cotransporter in rat brain. A neuronal-specific isoform. J Biol Chem 271:16245-16252.

Perkins KL (2006) Cell-attached voltage-clamp and current-clamp recording and stimulation techniques in brain slices. J Neurosci Methods 154:1-18.

Plotkin MD, Kaplan MR, Peterson LN, Gullans SR, Hebert SC, Delpire E (1997) Expression of the $\mathrm{Na}(+)-\mathrm{K}(+)-2 \mathrm{Cl}-$ cotransporter BSC2 in the nervous system. Am J Physiol 272:C173-183.

Popescu IR, Morton LA, Franco A, Di S, Ueta Y, Tasker JG (2010) Synchro- 
nized bursts of miniature inhibitory postsynaptic currents. J Physiol 588:939-951.

Prescott SA, Sejnowski TJ, De Koninck Y (2006) Reduction of anion reversal potential subverts the inhibitory control of firing rate in spinal lamina I neurons: towards a biophysical basis for neuropathic pain. Mol Pain 2:32.

Randle JC, Renaud LP (1987) Actions of gamma-aminobutyric acid on rat supraoptic nucleus neurosecretory neurones in vitro. J Physiol 387: 629-647.

Randle JC, Bourque CW, Renaud LP (1986a) Alpha 1-adrenergic receptor activation depolarizes rat supraoptic neurosecretory neurons in vitro. Am J Physiol 251:R569-R574.

Randle JC, Bourque CW, Renaud LP (1986b) Characterization of spontaneous and evoked inhibitory postsynaptic potentials in rat supraoptic neurosecretory neurons in vitro. J Neurophysiol 56:1703-1717.

Represa A, Ben-Ari Y (2005) Trophic actions of GABA on neuronal development. Trends Neurosci 28:278-283.

Rheims S, Holmgren CD, Chazal G, Mulder J, Harkany T, Zilberter T, Zilberter Y (2009) GABA action in immature neocortical neurons directly depends on the availability of ketone bodies. J Neurochem 110:13301338.

Rivera C, Voipio J, Payne JA, Ruusuvuori E, Lahtinen H, Lamsa K, Pirvola U, Saarma M, Kaila K (1999) The K+/Cl- co-transporter KCC2 renders GABA hyperpolarizing during neuronal maturation. Nature 397:251255.

Roberts MM, Robinson AG, Fitzsimmons MD, Grant F, Lee WS, Hoffman GE (1993) c-fos expression in vasopressin and oxytocin neurons reveals functional heterogeneity within magnocellular neurons. Neuroendocrinology 57:388-400.

Russell JM (2000) Sodium-potassium-chloride cotransport. Physiol Rev 80:211-276.

Simmons DM, Swanson LW (2009) Comparison of the spatial distribution of seven types of neuroendocrine neurons in the rat paraventricular nucleus: toward a global 3D model. J Comp Neurol 516:423-441.

Sipilä ST, Huttu K, Yamada J, Afzalov R, Voipio J, Blaesse P, Kaila K (2009) Compensatory enhancement of intrinsic spiking upon NKCC1 disruption in neonatal hippocampus. J Neurosci 29:6982-6988.

Song I, Savtchenko L, Semyanov A (2011) Tonic excitation or inhibition is set by GABA(A) conductance in hippocampal interneurons. Nat Commun 2:376.

Stern JE, Ludwig M (2001) NO inhibits supraoptic oxytocin and vasopressin neurons via activation of GABAergic synaptic inputs. Am J Physiol Regul Integr Comp Physiol 280:R1815-R1822.

Tasker JG, Dudek FE (1991) Electrophysiological properties of neurones in the region of the paraventricular nucleus in slices of rat hypothalamus. J Physiol 434:271-293.

Tasker JG, Dudek FE (1993) Local inhibitory synaptic inputs to neurones of the paraventricular nucleus in slices of rat hypothalamus. J Physiol 469:179-192.

Thellier D, Moos F, Richard P, Stoeckel ME (1994) Evidence for connections between a discrete hypothalamic dorsochiasmatic area and the supraoptic and paraventricular nuclei. Brain Res Bull 34:261-274.

Theodosis DT, Paut L, Tappaz ML (1986) Immunocytochemical analysis of the GABAergic innervation of oxytocin- and vasopressin-secreting neurons in the rat supraoptic nucleus. Neuroscience 19:207-222.

Tozuka Y, Fukuda S, Namba T, Seki T, Hisatsune T (2005) GABAergic excitation promotes neuronal differentiation in adult hippocampal progenitor cells. Neuron 47:803-815.

Tribollet E, Armstrong WE, Dubois-Dauphin M, Dreifuss JJ (1985) Extrahypothalamic afferent inputs to the supraoptic nucleus area of the rat as determined by retrograde and anterograde tracing techniques. Neuroscience 15:135-148.

Ueta Y, Fujihara H, Serino R, Dayanithi G, Ozawa H, Matsuda K, Kawata M, Yamada J, Ueno S, Fukuda A, Murphy D (2005) Transgenic expression of enhanced green fluorescent protein enables direct visualization for physiological studies of vasopressin neurons and isolated nerve terminals of the rat. Endocrinology 146:406-413.

Viitanen T, Ruusuvuori E, Kaila K, Voipio J (2010) The K+-Cl cotransporter KCC2 promotes GABAergic excitation in the mature rat hippocampus. J Physiol 588:1527-1540.

Vrang N, Larsen PJ, Møller M, Mikkelsen JD (1995) Topographical organization of the rat suprachiasmatic-paraventricular projection. J Comp Neurol 353:585-603.

Wagner S, Castel M, Gainer H, Yarom Y (1997) GABA in the mammalian suprachiasmatic nucleus and its role in diurnal rhythmicity. Nature 387:598-603.

Wardle RA, Poo MM (2003) Brain-derived neurotrophic factor modulation of GABAergic synapses by postsynaptic regulation of chloride transport. J Neurosci 23:8722-8732.

Woodin MA, Ganguly K, Poo MM (2003) Coincident pre-and postsynaptic activity modifies GABAergic synapses by postsynaptic changes in $\mathrm{Cl}-$ transporter activity. Neuron 39:807-820.

Woodruff AR, Monyer H, Sah P (2006) GABAergic excitation in the basolateral amygdala. J Neurosci 26:11881-11887.

Woodruff A, Xu Q, Anderson SA, Yuste R (2009) Depolarizing effect of neocortical chandelier neurons. Frontiers in neural circuits 3:15.

Wuarin JP (1997) Glutamate microstimulation of local inhibitory circuits in the supraoptic nucleus from rat hypothalamus slices. J Neurophysiol 78:3180-3186.

Wuarin JP, Dudek FE (1993) Patch-clamp analysis of spontaneous synaptic currents in supraoptic neuroendocrine cells of the rat hypothalamus. J Neurosci 13:2323-2331.

Zhang SJ, Jackson MB (1993) GABA-activated chloride channels in secretory nerve endings. Science 259:531-534. 